\title{
Evaluation of a new mathematical model to describe Clostridium perfringens growth during the cooling of cooked ground beef \\ Marcelo DECKER ${ }^{1}$, Gilmar de Almeida GOMES ${ }^{1}$, Alessandro Cazonatto GALVÃO ${ }^{1}$, Weber da Silva ROBAZZA ${ }^{1 *}$
}

\begin{abstract}
A mathematical model previously developed to study microbial growth in food products under an isothermal environment was adapted to a time-varying temperature regime. The resulting model was applied to study the growth of Clostridium perfringens in meat products. This micro-organism is of particular relevance to public health and economy due to the loss of productivity caused by it. Results showed a similar performance of the model used compared to the Baranyi model under an isothermal situation and a slightly better performance under a non-isothermal temperature profile.
\end{abstract}

Keywords: Clostridium perfringens; predictive microbiology; dynamical temperature profile.

\section{Introduction}

Clostridium perfringens is a Gram-positive, anaerobic, spore-forming bacterium. It is found in the intestine of humans and animals. Consequently, raw protein foods of animal origin can be easily contaminated with Clostridium perfringens (JUNEJA; MARKS; THIPPAREDDI, 2010). It is estimated that this organism is responsible for 248,500 cases of diarrhea per year in the USA (MEAD; SLUTSKER; DIETZ, 1999), and there are still many cases of under-reporting and under-diagnosis (SCALLAN et al., 2011). In addition, this pathogen is of particular concern in cooked meat products because it is a spore former and it is one of the most rapidly growing bacteria with generation times as short as $7.1 \mathrm{~min}$ at temperatures between 43 to $46^{\circ} \mathrm{C}$ (AMÉZQUITA et al., 2005).

Improper cooling may allow growth of Clostridium perfringens in meat products since the mathematically predicted minimal temperature growth of this pathogen is $10.5^{\circ} \mathrm{C}$ (JUNEJA et al., 1999; DE JONG; ROMBOUTS; BEUMER, 2004). On the other hand, Clostridium perfringens growth has been observed at temperatures as high as $50{ }^{\circ} \mathrm{C}$ (NOVAK; JUNEJA, 2002).

There is a large variety of meat products with various methods of processing, packaging, storage, and distribution. Thus, there is no single microbiology for meat products (McDONALD; SUN, 1999). However, a single equation which summarizes microbial responses to significant factors such as temperature and curing ingredients can be used to provide assessments of possible microbial spoilage (ROSS; McMEEKIN, 1995). In this respect, a number of mathematical models have been employed to predict Clostridium perfringens growth parameters during the cooling of cooked meat products (JUNEJA et al., 1999, 2001; HUANG, 2003a, b; JUNEJA; MARKS, 2002; AMÉZQUITA et al., 2005; SMITHSIMPSON; SCHAFFNER, 2005; SMITH-SIMPSON et al., 2007; LE MARC et al., 2008; JUNEJA; MARKS; THIPPAREDDI, 2006, 2008, 2010).

The use of equations and mathematical models to predict microbial growth is in the scope of the predictive microbiology. It consists in a quantitative science that enables users to evaluate objectively the effect of processing, distribution, and storage operations on the microbiological safety and quality of foods (McMEEKIN et al., 1993). The models found more often in the above mentioned field are the modified Gompertz model (GIBSON; ROBERTS, 1986; GIBSON; BRATCHELL; ROBERTS, 1988) and the Baranyi model (BARANYI; ROBERTS; McCLURE, 1993; BARANYI; ROBERTS, 1994). In general, it is considered that the Baranyi model provides a better goodness of fit than the modified Gompertz equation. In addition, the modified Gompertz model lacks a mechanistic basis, and the Baranyi model provides a biological interpretation for the lag phase (BARANYI; ROBERTS, 1995).

Many authors have developed mathematical models for dynamic temperatures, but their performances have not always been satisfactory (FUJIKAWA; KAI; MOROZUMI, 2004). In this context, this study aims to apply and validate a previously developed mathematical model (TELEKEN; ROBAZZA; GOMES, 2011) to predict the growth of Clostridium perfringens in ground beef at isothermal temperatures and at two cooling profiles. Another objective is to compare this model with the Baranyi model using published experimental data.

\footnotetext{
Received 19/2/2013

Accepted 15/5/2013(006024)

1 Departamento de Engenharia de Alimentos, Universidade do Estado de Santa Catarina - UDESC, BR 282, Km 573,7 CEP 89870-000, Pinhalzinho, SC, Brasil, e-mail:wrobazzi@yahoo.com.br

${ }^{*}$ Corresponding author
}

DOI: http://dx.doi.org/10.1590/S0101-20612013005000060 


\section{Materials and methods}

\subsection{Experimental data}

Four different datasets of isothermal growth of Clostridium perfringens in meat products were selected from Combase, a database that encompasses observations of bacterial responses to food environments (BARANYI; TAMPLIN, 2004). In addition, published data of non-isothermal growth of Clostridium perfringens in ground beef were obtained from the literature (VAN BOEKEL, 2008). In order to study non-isothermal growth, two cooling curves were employed. In curve $\mathrm{A}$, first dataset, temperatures ranged between $44.0{ }^{\circ} \mathrm{C}$ and $26.6{ }^{\circ} \mathrm{C}$ during a time interval of $3.6 \mathrm{~h}$, and in curve $\mathrm{B}$, second dataset, temperatures ranged between $45.7^{\circ} \mathrm{C}$ and $21.3^{\circ} \mathrm{C}$ during a time interval of $11.0 \mathrm{~h}$ (VAN BOEKEL, 2008). The evaluation of isothermal growth was based on this temperature range, i.e., the temperatures adopted ranged between $23^{\circ} \mathrm{C}$ and $43{ }^{\circ} \mathrm{C}\left(23^{\circ} \mathrm{C}\right.$, $28^{\circ} \mathrm{C}, 33^{\circ} \mathrm{C}$, and $43^{\circ} \mathrm{C}$, respectively).

\subsection{Mathematical model}

In this study, a previously developed mathematical model, denominated the TRG model, was used (TELEKEN; ROBAZZA; GOMES, 2011). The original model is composed by the two following differential equations:

$\frac{d N(t)}{d t}=\mu(N) \cdot N(t)$

where $N(t)$ expresses the logarithm of the microbial load at time $t$ and $\mu(N)$ is the specific growth rate.

$$
\frac{d \mu(N)}{d N}=-\alpha \cdot N^{m}
$$

where $\alpha$ is a positive parameter which depends only on the environmental variables (e.g. temperature, $\mathrm{pH}$ ) and $m$ is a shape parameter with no biological meaning.

Equation 1 is commonly found in all of the mathematical models used in predictive food microbiology (BARANYI; ROBERTS, 1995). The main novelty of the model used in this study consists in the introduction of Equation 2 and the hypothesis that the specific growth rate must be a decreasing function of the microbial population due to nutrient depletion and metabolite accumulation (TELEKEN; ROBAZZA; GOMES, 2011).

The solution of the system composed by Equations 1 and 2 when $m \neq-1$ is given by Equation 3:

$$
N(t)=N_{0}\left\{\frac{\mu_{0}(m+1)+\alpha N_{0}^{m+1}}{\mu_{0}(m+1) e^{-t\left[\mu_{0}(m+1)+\alpha N_{0}^{m+1}\right]}+\alpha N_{0}^{m+1}}\right\}^{\frac{1}{m+1}}
$$

where $N_{0}$ is the initial log count of the microbial population and $\mu_{0}$ is the initial specific growth rate.

In order to fit the TRG growth model to the experimental data, Equation 3 can be rewritten after replacement of the empirical parameter $\alpha$ with the maximum microbial load, $N_{f}$ In the original study, it was shown that (TELEKEN; ROBAZZA; GOMES, 2011):

$N(t)=N_{f}\left\{\left(\frac{N_{f}^{m+1}-N_{0}^{m+1}}{N_{0}^{m+1}}\right) e^{-t \cdot\left[\frac{\mu_{0}(m+1) N_{m}^{m+1}}{N_{f}^{m+1}-N_{0}^{m+1}}\right]}+1\right\}^{\frac{-1}{m+1}}$

Equation 4 is valid to situations where the parameter $\alpha$ remains constant (e.g. isothermal growth). However, in this study, it was considered a non-isothermal growth. In this case, this parameter is assumed as being time dependent, and a new equation must be used in order to describe growth in such condition. To accomplish this task, the Ratkowsky extended square-root model was adopted as a secondary model (RATKOWSKY et al., 1982, 1983):

$\alpha(T)=\sqrt{\mu_{\max }}\left(T(t)-T_{\min }\right) e^{c\left(T(t)-T_{\max }\right)}$

where $\mu_{\max }$ is the maximum specific growth rate, $T_{\min }$ and $T_{\max }$ are the minimum and maximal temperature at which growth is observed, $T(t)$ expresses the dynamical profile of temperature as a function of time, and $c$ is an empirical parameter.

In a non-isothermal situation, it can be shown, after some algebra, that the solution of the system formed by Equations 1 and 2 becomes:

$N(t)=N_{0} e^{\mu_{0} t}\left\{\frac{1}{1+N_{0}^{m+1} \int_{0}^{t} \alpha(t) e^{\mu_{0}(m+1) t}}\right\}^{\frac{1}{m+1}}$

where $\alpha(t)$ is given by Equation 5 and the temperature dependence, $T(t)$, is empirically obtained for the situation being evaluated.

\subsection{Fitting procedure}

\section{Isothermal growth}

The fitting procedure adopted for isothermal growth with TRG model was similar to the one previously employed (TELEKEN; ROBAZZA; GOMES, 2011). It consisted of fitting Equation 4 to the experimental data. The following parameters with biological meaning were estimated: the duration of the lag phase, $t_{\mathrm{lag}}$, as defined by Buchanan and Cygnarowicz (1990), the time of ending of the exponential phase, $t_{\exp }$, the maximum specific growth rate, $\mu_{\max }$, and the logarithmic growth of the population, $A=N_{\mathrm{f}}-N_{0}$.

In order to fit the Baranyi model to the isothermal growth data, DMFit 2.1 was used. This mathematical software consists of an Excel add-in that fits curves where a linear phase is preceded and followed by a stationary phase to the Baranyi mathematical model (BARANYI; ROBERTS, 1994).

\section{Non-isothermal growth}

In order to fit the TRG model to the experimental data of non-isothermal growth of Clostridium perfringens, the calculations comprised the following steps: 
- An empirical function of temperature was fitted to the experimental data using the curve-fitting software Origin 6.0 ;

- The expression obtained was inserted into Equation 5;

- Equation 6 was numerically integrated, and the resulting function was fitted to the experimental data of Clostridium perfringens using the mathematical package Mathcad 2000 Professional.

For comparison purposes, Combase Predictor 2.0 platform was used to fit the Baranyi growth model to the non-isothermal datasets being studied. This predictive modeling software is freely available in the predictive microbiology database Combase (www.combase.cc). In order to model Clostridium perfringens growth, this database comprises a set of 51 observed growth curves of this micro-organism that are used to generate the growth models. For the models developed in Combase Predictor 2.0, a second order polynomial equation models the effect of temperature on the rates obtained by the primary models. The range of temperatures available for modeling the growth of this micro-organism is between $15^{\circ} \mathrm{C}$ and $52^{\circ} \mathrm{C}$ and it can predict growth parameters for both isothermal and nonisothermal growth.

\subsection{Statistical analysis}

In order to evaluate the performance of the models, the following statistical indexes were used: root mean square error (RMSE), the bias (FB), and accuracy (FAC) factors, which are defined by the following Equations 7, 8, 9 (ROSS, 1996):

$$
\begin{aligned}
& R M S E=\frac{1}{n-p} \cdot \sqrt{\sum_{i=1}^{n}\left(p r_{i}-o b_{i}\right)^{2}} \\
& F B=10^{\frac{1}{n} \sum_{i=1}^{n} \log \left(\frac{p r_{i}}{o b_{i}}\right)} \\
& F A C=10^{\frac{1}{n} \sum_{i=1}^{n} \mid \log \left(\frac{p r_{i}}{o b_{i}}\right)}
\end{aligned}
$$

where $n$ is the number of experimental points, $p r_{i}$ is the result predicted by the mathematical model, $o b s_{i}$ is the experimental datum, and $p$ is the number of parameters in the model.

All of the statistical indexes used in this study were calculated using the software Mathcad 2000 Professional.

\section{Results and discussion}

\subsection{Isothermal environment}

Figures 1 and 2 show, respectively, the curves obtained after the fit of the TRG model to the four datasets used in this study and the fit of the Baranyi model, obtained with DMFit 2.1, to the growth at $33^{\circ} \mathrm{C}$. Table 1 exhibits the biological parameters estimated for each of the models being evaluated and the statistical indexes obtained for both models.

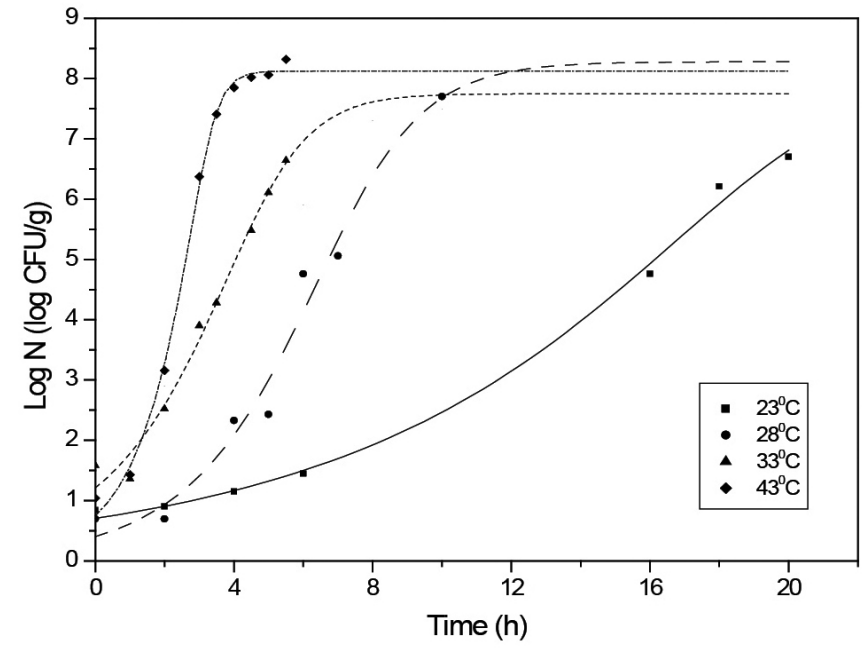

Figure 1. Fit of TRG model to isothermal growth data.

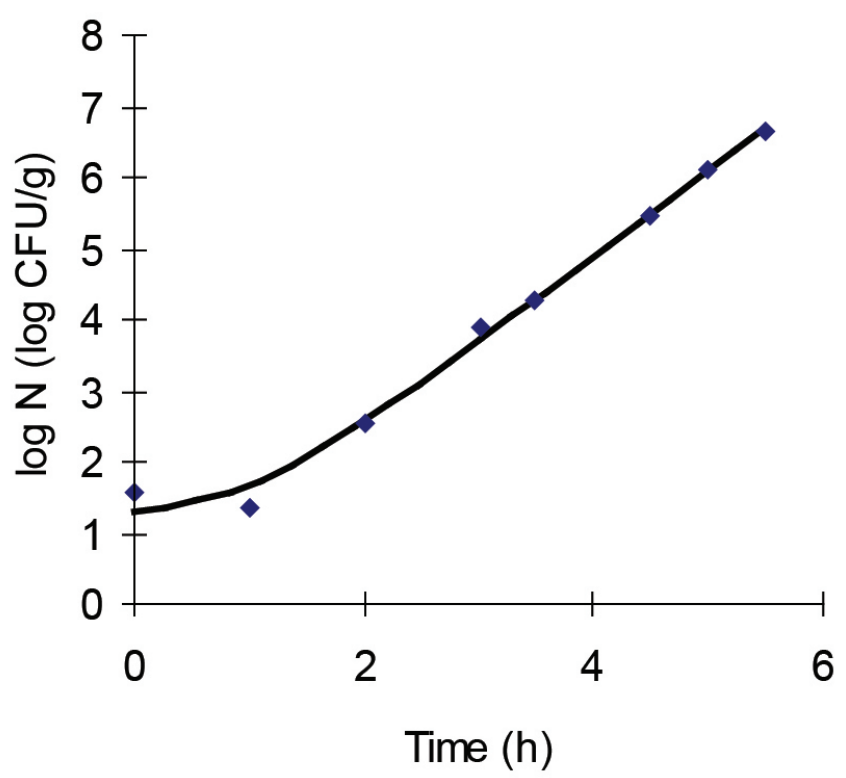

Figure 2. Fit of Baranyi model to the experimental data of isothermal growth at $33^{\circ} \mathrm{C}$.

It can be seen from results shown in Table 1 that for growth at the temperatures of $23^{\circ} \mathrm{C}$ and $28^{\circ} \mathrm{C}$, the TRG model exhibited a slightly better performance, as suggested by FAC and $\mathrm{R}^{2}$ values. However, the FB results indicated that TRG model predicts, in general, log counts lower than the actual observed data, and the BAR model predicts log counts larger than the experimentally observed results. From a food safety perspective, the latter situation is preferred because an overestimation is more desirable than an underestimation of microbial growth. For the temperatures of $33^{\circ} \mathrm{C}$ and $43^{\circ} \mathrm{C}$, the statistical indexes suggested a better performance of the BAR model.

The results obtained for the duration of the lag phase were larger for the TRG model, but this is more likely an effect of the procedure adopted in the calculation of $t_{\text {lag }}$ than a difference between the models being studied (BATY; DELIGNETTE- 
Table 1. Biological parameters obtained for isothermal growth (TRG: Teleken, Robazza, Gomes and BAR: Baranyi).

\begin{tabular}{|c|c|c|c|c|c|c|c|c|}
\hline & \multicolumn{4}{|c|}{ TRG Model } & \multicolumn{4}{|c|}{ BAR Model } \\
\hline & $23^{\circ} \mathrm{C}$ & $28^{\circ} \mathrm{C}$ & $33^{\circ} \mathrm{C}$ & $43^{\circ} \mathrm{C}$ & $23^{\circ} \mathrm{C}$ & $28^{\circ} \mathrm{C}$ & $33^{\circ} \mathrm{C}$ & $43^{\circ} \mathrm{C}$ \\
\hline$\mu_{\max }(1 / h)$ & 0.502 & 1.209 & 1.296 & 3.253 & 0.437 & 0.753 & 1.195 & 3.127 \\
\hline$t_{\text {lag }}(\mathrm{h})$ & 12.119 & 4.242 & 2.056 & 2.114 & 6.722 & $\mathrm{np}$ & 1.009 & 1.347 \\
\hline$t_{\exp }^{\circ}(\mathrm{h})$ & 21.147 & 8.507 & 5.535 & 3.393 & ne & ne & ne & ne \\
\hline$A(\log \mathrm{UFC} / \mathrm{g})$ & 7.557 & 7.872 & 6.535 & 7.378 & 5.809 & 7.001 & 5.367 & 6.963 \\
\hline RMSE & 0.127 & 0.333 & 0.154 & 0.088 & 0.161 & 0.576 & 0.116 & 0.071 \\
\hline FB & 0.983 & 0.965 & 0.997 & 0.976 & 1.006 & 1.162 & 1.001 & 1.001 \\
\hline FAC & 1.049 & 1.214 & 1.084 & 1.061 & 1.083 & 1.237 & 1.062 & 1.031 \\
\hline$R^{2}$ & 0.996 & 0.975 & 0.987 & 0.997 & 0.992 & 0.910 & 0.990 & 0.997 \\
\hline
\end{tabular}

np: the Baranyi growth model did not predict a lag phase at $28^{\circ} \mathrm{C}$. ne: DMFit does not estimate the duration of the exponential phase.

MULLER, 2004). As for the other parameters, the results of the maximum specific growth rate obtained for both models were close to each other and the logarithmic growth, $A$, predicted by the TRG model was higher for all temperatures studied. This behavior can be ascribed to an underestimation of the initial log count obtained after the fit of the experimental data to the TRG model, as can be seen in Figure 1.

\subsection{Non-isothermal environment}

Figure 3 shows the cooling profiles used in this study. As previously mentioned, in the first dataset, the temperatures ranged between $44.0^{\circ} \mathrm{C}$ and $26.6^{\circ} \mathrm{C}$ during a time interval of $3.6 \mathrm{~h}$ and in the second, the temperature range was between $45.7^{\circ} \mathrm{C}$ and $21.3^{\circ} \mathrm{C}$ during a time interval of $11.0 \mathrm{~h}$.

In Figures 4 and 5, it is presented the fit of the TRG model to the two datasets of non-isothermal growth shown in Figure 3. The curves presenting results obtained for the BAR model after the fit of the growth data using Combase Predictor 2.0 are very similar and were not included in this study. Table 2 summarizes the statistical indexes obtained for the two datasets and both models being studied.

It can be seen from the results shown in Table 2 that RMSE and FAC values were lower for the TRG model in the two datasets being studied. The BAR model resulted in a lower level of FB for the second dataset, but it resulted in a value lower than 1 for the first dataset, thus leading to an underestimation of the microbial growth, which is not desirable in terms of food safety policies. Therefore, from both fit and food safety perspectives, it can be considered that the TRG model had a slightly better performance than that of the BAR model for the two datasets of non-isothermal growth used in this study.

Another point that deserves attention is the number of parameters of each model. Although the TRG primary model has a lower number of parameters (4) than those of the Baranyi growth model (6 parameters), it is difficult to compare these models because they are based on very different mathematical and biological hypothesis. Actually, the main advantage of the Baranyi model lies not on its number of parameters, which can be considered as relatively high, but it also lies on the fact that it is considered the most mechanistic model in the literature (VADASZ; VADASZ, 2007).

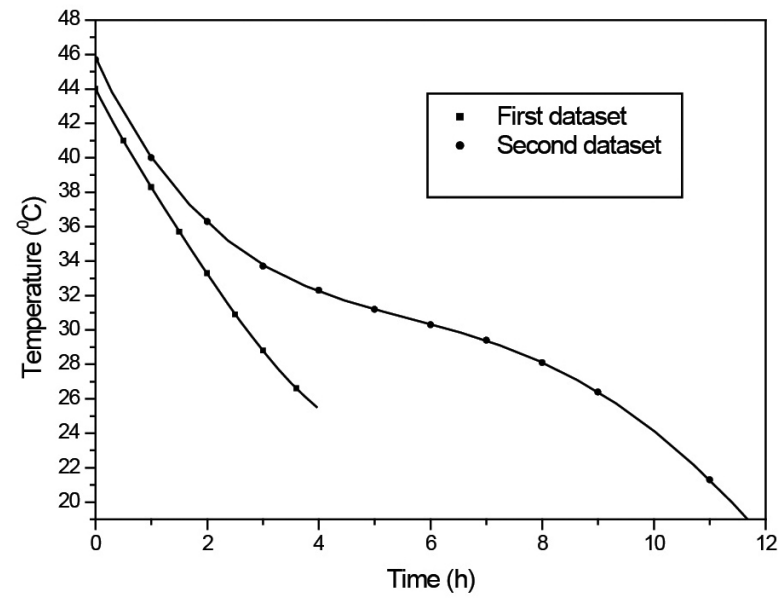

Figure 3. Temperature profiles used in this study for non-isothermal growth.

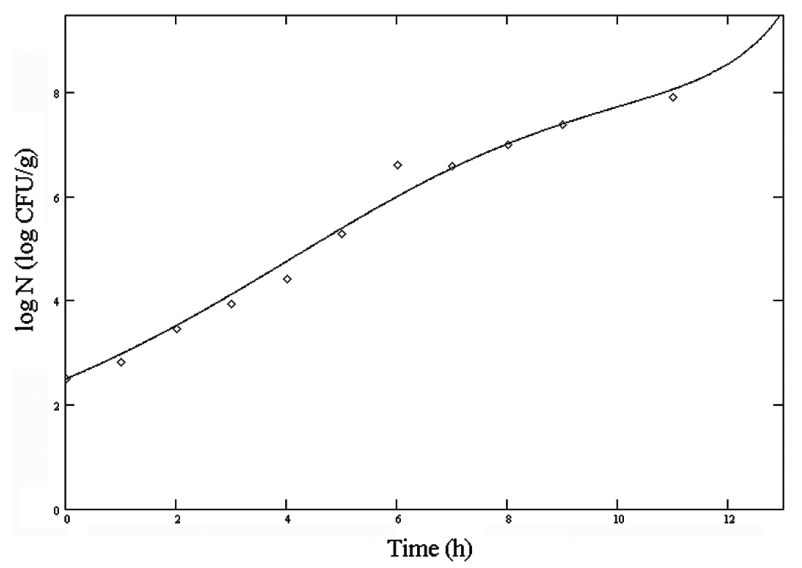

Figure 4. Fit of the TRG model to the experimental data of the first dataset of non-isothermal growth of Clostridium perfringens.

Table 2. Statistical indexes obtained for non-isothermal growth (TRG: Teleken, Robazza, Gomes and BAR: Baranyi).

\begin{tabular}{lccc}
\hline \multicolumn{1}{c}{ Dataset } & RMSE & FB & FAC \\
\hline TRG - First Dataset & 0.131 & 1.026 & 1.061 \\
BAR - First Dataset & 0.180 & 0.982 & 1.079 \\
TRG - Second Dataset & 0.156 & 1.032 & 1.092 \\
BAR - Second Dataset & 0.265 & 1.017 & 1.152 \\
\hline
\end{tabular}




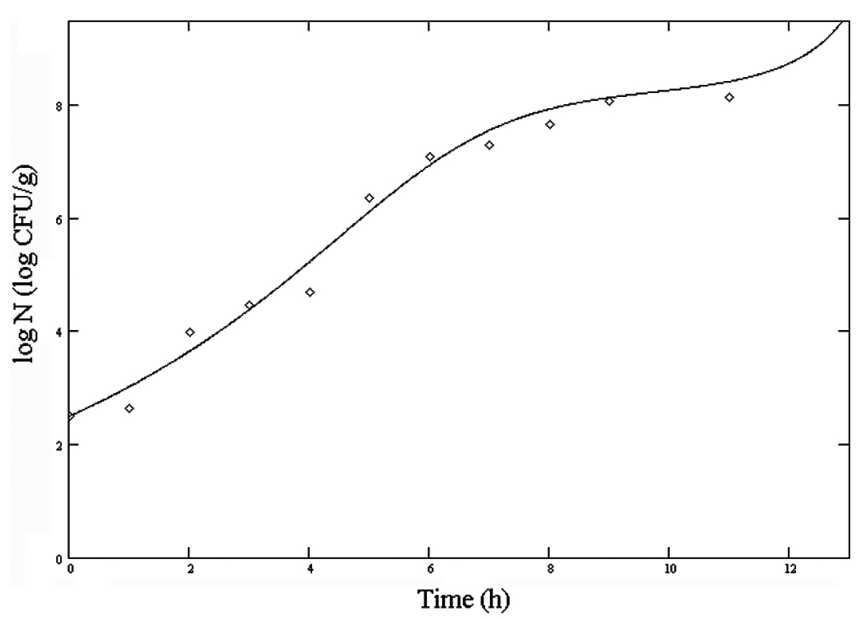

Figure 5. Fit of the TRG model to the experimental data of the second dataset of non-isothermal growth of Clostridium perfringens.

\section{Conclusions}

The main objective of this study was to apply and validate a previous developed mathematical model to microbial growth in food products under an isothermal environment to a non-isothermal temperature profile. The results obtained with the TRG model were compared with those of the Baranyi model, which is the most commonly used model in predictive microbiology literature. Both models, TRG and BAR, exhibited a similar performance in an isothermal regime, and the results showed that the TRG model had a slightly superior performance in non-isothermal temperature profiles. From a microbiological point of view, the Baranyi growth model can still be considered as being the one with a mechanistic basis because it takes into account underlying biological phenomena in its derivation. However, the TRG model and other models, such as the modified Gompertz growth model, can also be safely fitted to experimental data and provide useful insights that may help to promote food safety.

\section{Acknowlegments}

The authors are grateful for the scholarship provided by Santa Catarina State University as part of the Institutional Program of Scientific Training - PROIP/UDESC.

\section{References}

AMÉZQUITA, A. et al. Development of an integrated model for heat transfer and dynamic growth of Clostridium perfringens during the cooling of cooked boneless ham. International Journal of Food Microbiology, v. 101, p. 123-144, 2005. PMid:15862875. http:// dx.doi.org/10.1016/j.ijfoodmicro.2004.10.041

BARANYI, J.; ROBERTS, T. A. A dynamic approach to predicting bacterial growth in food. International Journal of Food Microbiology, v. 23, p. 277-294, 1994. http://dx.doi. org/10.1016/0168-1605(94)90157-0

BARANYI, J.; ROBERTS, T. A. Mathematics of predictive food microbiology. International Journal of Food Microbiology, v. 26, p. 199-218, 1995. http://dx.doi.org/10.1016/0168-1605(94)00121-L
BARANYI, J.; ROBERTS, T. A.; McCLURE, P. A non-autonomous differential equation to model bacterial growth. Food Microbiology, v. 10, p. 43-59, 1993. http://dx.doi.org/10.1006/fmic.1993.1005

BARANYI, J.; TAMPLIN, M. L. ComBase: a common database on microbial responses to food environments. Journal of Food Protection, v. 67, p. 1967-1971, 2004. PMid:15453591.

BATY, F.; DELIGNETTE-MULLER, M.-L. Estimating the bacterial lag time: which model, which precision? International Journal of Food Microbiology, v. 91, p. 261-277, 2004. PMid:14984774. http:// dx.doi.org/10.1016/j.ijfoodmicro.2003.07.002

BUCHANAN, R. L.; CYGNAROWICZ, M. L. A mathematical approach toward defining and calculating the duration of the lag phase. Food Microbiology, v. 7, p. 237-240, 1990. http://dx.doi. org/10.1016/0740-0020(90)90029-H

DE JONG, A. E. I.; ROMBOUTS, F. M.; BEUMER, R. R. Behavior of Clostridium perfringens at low temperatures. International Journal of Food Microbiology, v. 97, p. 71-80, 2004. PMid:15527920. http:// dx.doi.org/10.1016/j.ijfoodmicro.2004.03.030

FUJIKAWA, H.; KAI, A.; MOROZUMI, S. A new logistic model for Escherichia coli growth at constant and dynamic temperatures. Food Microbiology, v. 21, p. 501-509, 2004. http://dx.doi.org/10.1016/j. fm.2004.01.007

GIBSON, A.; BRATCHELL, N.; ROBERTS, T. A. Predicting microbial growth: growth responses of Salmonellae in a laboratory medium as affected by $\mathrm{pH}$, sodium chloride and storage temperature. International Journal of Food Microbiology, v. 6, p. 155-178, 1988. http://dx.doi.org/10.1016/0168-1605(88)90051-7

GIBSON, A.; ROBERTS, T. A. The effect of $\mathrm{pH}$, sodium chloride, sodium nitrite and storage temperature on the growth of Clostridium perfringens and faecal streptococci in laboratory media. International Journal of Food Microbiology, v. 3, p. 195-210, 1986. http://dx.doi.org/10.1016/0168-1605(86)90023-1

HUANG, L. Dynamic computer simulation of Clostridium perfringens growth in cooked ground beef. International Journal of Food Microbiology, v. 87, p. 217-227, 2003a. http://dx.doi.org/10.1016/ S0168-1605(03)00065-5

HUANG, L. Estimation of growth of Clostridium perfringens growth in cooked beef under fluctuating temperature conditions. Food Microbiology, v. 20, p. 549-559, 2003b. http://dx.doi.org/10.1016/ S0740-0020(02)00155-7

JUNEJA, V. K.; MARKS, H. M. Predictive model for growth of Clostridium perfringens during cooling of cooked cured chicken. Food Microbiology, v. 19, p. 313-327, 2002. http://dx.doi. org/10.1006/fmic.2002.0486

JUNEJA, V. K.; MARKS, H. M.; THIPPAREDDI, H. H. Predictive model for growth of Clostridium perfringens in cooked cured pork. International Journal of Food Microbiology, v. 110, p. 85-92, 2006. PMid:16697066. http://dx.doi.org/10.1016/j. ijfoodmicro.2006.01.038

JUNEJA, V. K.; MARKS, H. M.; THIPPAREDDI, H. H. Predictive model for growth of Clostridium perfringens during cooling of cooked uncured beef. Food Microbiology, v. 25, p. 42-55, 2008. PMid:17993376. http://dx.doi.org/10.1016/j.fm.2007.08.004

JUNEJA, V. K.; MARKS, H. M.; THIPPAREDDI, H. H. Predictive model for growth of Clostridium perfringens during cooling of cooked ground pork. Innovative Food Science and Emerging Technologies, v. 11, p. 146-154, 2010. http://dx.doi.org/10.1016/j. ifset.2009.10.010

JUNEJA, V. K. et al. Growth of Clostridium perfringens from spore inocula in cooked cured beef: development of a predictive model. 
Innovative Food Science and Emerging Technologies, v. 2, p. 289-301, 2001. http://dx.doi.org/10.1016/S1466-8564(01)00050-9

JUNEJA, V. K. et al. Modeling the effect of temperature on growth of Salmonella in chicken. Food Microbiology, v. 24, p. 328-335, 2007. PMid:17189758. http://dx.doi.org/10.1016/j.fm.2006.08.004

JUNEJA, V. K. et al. Predictive model for growth of Clostridium perfringens at temperatures applicable to cooling of cooked meats. Food Microbiology, v. 16, p. 335-349, 1999. http://dx.doi. org/10.1006/fmic.1998.0245

LE MARC, Y. et al. Modelling the growth of Clostridium perfringens during the cooling of bulk meat. International Journal of Food Microbiology, v. 128, p. 41-50, 2008. PMid:18768233. http://dx.doi. org/10.1016/j.ijfoodmicro.2008.07.015

McDONALD, K.; SUN, D. W. Predictive food microbiology for the meat industry: a review. International Journal of Food Microbiology, v. 52, p. 1-27, 1999. http://dx.doi.org/10.1016/ S0168-1605(99)00126-9

McMEEKIN, T. A. et al. Predictive Microbiology: Theory and Application. Taunton: Research Studies Press Ltd., 1993.

MEAD, P. S.; SLUTSKER, L.; DIETZ, V. Food-related illness and death in the United States. Emerging Infectious Diseases, v. 5, p. 607-625, 1999. PMid:10511517 PMCid:PMC2627714. http:// dx.doi.org/10.3201/eid0505.990502

NOVAK, J. S.; JUNEJA, V. K. Clostridium perfringens: hazards in new generation foods. Innovative Food Science and Emerging Technologies, v. 3, p. 127-132, 2002. http://dx.doi.org/10.1016/ S1466-8564(02)00011-5

RATKOWSKY, D. A. et al. Relationship between temperature and growth rate of bacterial cultures. Journal of Bacteriology, v. 149, p. 1-5, 1982. PMid:7054139 PMCid:PMC216584.

RATKOWSKY, D. A. et al. Model for bacterial growth throughout the entire biokinetic temperature range. Journal of Bacteriology, v. 154, p. 1222-1226, 1983. PMid:6853443 PMCid:PMC217594.
ROSS, T.; McMEEKIN, T. A. Predictive microbiology and HACCP. In: PEARSON, A. M.; DUTSON, T. R. Advances in Meat Research: HACCP in Meat, Poultry and Fish Processing. Chapman and Hall, 1995. chapt. 10, p. 330-357. http://dx.doi.org/10.1007/978-1-46152149-5_13

ROSS, T. Indices for performance evaluation of predictive models in food microbiology. Journal of Applied Bacteriology, v. 81, p. 501-508, 1996. PMid:8939028.

SCALLAN, E. et al. Foodborne illness acquired in the United States - Major pathogens. Emerging Infectious Diseases, v. 17, p. 7-15, 2011. PMid:21192848 PMCid:PMC3375761.

SMITH-SIMPSON, S. et al. Estimating microbial growth parameters from non-isothermal data: A case study with Clostridium perfringens. International Journal of Food Microbiology, v. 118, p. 294-303, 2007. PMid:17804106. http://dx.doi.org/10.1016/j. ijfoodmicro.2007.08.005

SMITH-SIMPSON, S.; SCHAFFNER, D. W. The development of a model to predict growth of Clostridium perfringens in cooked beef during cooling. Journal of Food Protection, v. 68, p. 336-341, 2005. PMid:15726978.

TELEKEN, J. T.; ROBAZZA, W. S.; GOMES, G. A. Mathematical modeling of microbial growth in milk. Ciência e Tecnologia de Alimentos, v. 31, p. 891-896, 2011.

VADASZ, P.; VADASZ, A. S. Biological implications from an autonomous version of Baranyi and Roberts growth model. International Journal of Food Microbiology, v. 114, p. 357-365, 2007. PMid:17140684. http://dx.doi.org/10.1016/j.ijfoodmicro.2006.10.010

VAN BOEKEL, M. A. J. S. Kinetics of microbial growth. In: VAN BOEKEL, M. A. J. S. Kinetic Modeling of Reactions in Foods. Boca Raton: CRC Press, 2008. chapt. 12, p. 12.1-12.43. http://dx.doi. org/10.1201/9781420017410.ch12 